\title{
DOMESTIC EXPERIENCE OF TRAINING FUTURE FOREIGN LANGUAGE TEACHERS USING INTERACTIVE TECHNOLOGIES
}

The article deals with some issues of training future foreign language teachers and the formation of their foreign language communicative competence using interactive technologies in higher educational institutions of Ukraine. It is mentioned that communicative competence, as a guarantee of professional development of future teachers of foreign languages, has occupied a leading position from historical point of view. The article highlights the competences that a future foreign language teacher should acquire. The faculties where professional training of teachers of foreign languages in Ukrainian higher educational institutions takes place have been identified. The list of leading universities of Ukraine where future foreign language teachers are trained has been provided. The article highlights the areas of specializations at foreign language faculties, which have become the most popular among Ukrainian students. It has been found that over the last decade, there has been a growing trend in the number of applicants to study at the faculties of foreign philology. Particular attention is paid to the specialization area 014.02 'Secondary education (Language and literature (with the indication of a language)' regarding the benefits of studying this area of specialization with the definition of compulsory subjects included in the educational programme. As part of the professional training of future foreign language teachers majoring in 014.02, leading Ukrainian higher educational institutions offer a cycle of general training, which consists of humanitarian and fundamental training, as well as a cycle of professional training, which includes psychological and pedagogical training. The article states that the foreign language communicative competence of future foreign language teachers is an integral part of their professional competence, as well as covers the elements of foreign language communicative competence. In order to form foreign language communicative competence of future foreign language teachers, Ukrainian higher educational institutions introduce a number of methods, including interactive technologies, in the course of teaching a foreign language, which are listed in the article.

Key words: domestic experience, interactive technologies, professional competence, foreign language communicative competence, professional training.

Problem statement. Currently, higher educational institutions of Ukraine attach particular importance to the issue of professional training of teachers of foreign languages, in particular the formation of their foreign language communicative competence. Modern language education is characterized by interdisciplinary integration, orientation towards the intercultural aspect, variability, etc., which, in its turn, implies the training of a foreign language teacher of a new generation. We believe that the use of interactive technologies in the course of professional training of teachers of foreign languages will help to achieve the goals mentioned above. In order to get better understanding about the state of training of teachers of foreign languages and perform objective evaluation of problems in the development of their foreign language communicative competence while using interactive technologies, we consider that it is necessary to study domestic experience in this matter.

Analysis of recent research and publications. The analysis of recent research and publications has demonstrated that the issue of state and improvement of professional training of future foreign languages teachers remains very important among Ukrainian researchers (M. Pentylyuk,
O. Popova, V. Semichenko, O. Tsaryk, O. Semenog, M. Ikonnikova). The issues of interactive learning technologies have been studied by such Ukrainian researchers as $\mathrm{O}$. Pometun, L. Pyrozhenko, G. Selevko and others. O. Vovk, M. Cherniy and others devoted their studies to the issues of modern approaches to the formation of communicative competence of future teachers.

Highlighting previously unsolved issues of the common problem. Despite the fact that Ukrainian researchers pay a lot of attention to the problems of training of teachers of foreign languages in higher educational institutions, we still consider it appropriate to overview domestic experience in the context of training future foreign language teachers in order to objectively identify which other improvements can be further implemented in this matter.

The purpose of this article is to outline domestic experience in the formation of foreign language communicative competence of future teachers of foreign languages in higher educational institutions using interactive learning technologies.

Main body. Ukraine does not stand aside from the integration of the latest methods and techniques of teaching in the educational process. The content and 
principles of the organization of professional training of teachers of foreign languages are conditioned by modern changes of the educational paradigm of Ukraine. However, knowledge of foreign languages remains the mainstay for a language teacher.

O.M. Tsaryk [12, p. 312-315] researched that as early as the beginning of the twentieth century, when the Ukrainian lands were part of the Austro-Hungarian Empire, there was a strong impetus to schooling and acceleration of the educational movement. In 1866-1867, Western Ukrainian schools actively introduced teaching of the Polish and German languages as foreign ones. These languages were taught 14 hours a week throughout the study period. School curricula were generalized, and the teacher independently, in accordance with the needs of the region, filled them with the necessary content. Therefore, the training of a language teacher who could cope with the requirements of that time was rather special. Future foreign language teachers had to take courses in philosophy, psychology, pedagogy, methodology of teaching the subject, a course in school hygiene, physical education, and a foreign language course, as well as to attend lectures and seminars on the stylistics of Latin and Greek languages, archeology. Future foreign language teachers had to be fluent in the language, have a good pronunciation, and have the skills of correct oral and written speech. Thus, we can say that the communicative component has historically occupied a leading place in the pedagogical skills of foreign language teachers.

Modern researchers also do not stand aside from the studies dedicated to the improvement of the training process of future foreign language teachers. M.I. Pentyliuk [7, p. 2-6] notes that the training of foreign language teachers requires new approaches and strategies that will meet the modern challenges of society. The task is to cultivate respect for the language, to ensure high-quality command of it, to provide an understanding of the role of a language in society.

In Ukrainian science, O.M. Semenog was the first who made an attempt to analyze the training of language teachers. She also developed her own model of the system of professional training of language teachers $[10$, p. 28]. The researcher singles out such competences of a language teacher as communicative, linguistic, pedagogical and others. V.A. Semichenko made the most detailed analysis of the training of philologists and proposed to improve the technological component of professional training of teachers of foreign languages [11, p. 3-43]. O.I. Vovk [2, p. 256] developed a functional model of formation of communicative and cognitive competence of philologists: polymodal acquaintance with a new material, its primary reproduction, cognitive perception, derivation of new knowledge, in-depth processing of information, use of acquired knowledge in productive speech. At the last stage, the cognitive and communicative readiness of future foreign language teachers for the cognitive and communicative process is implemented. Thus, the content of educational programmes for future foreign language teachers should contain basic provisions for communicative and cognitive approach to language teaching to ensure the readiness of future foreign language teachers for professional activities.

In Ukraine, foreign language teacher training is carried out in pedagogical and classical universities at philological faculties, foreign language faculties, in higher educational institutions of the third level of accreditation, which have a pedagogical orientation, at the institute of linguistics.

Currently, according to the site osvita.ua [6], professional training of future language teachers is carried out in 150 higher educational institutions of Ukraine among which there are the following ones: Interregional Academy of Personnel Management, Berdyansk State Pedagogical University, Vinnytsia Mykhailo Kotsiubynskyi State Pedagogical University, Eastern European Slavic University, Lesya Ukrainka Eastern European National University, PereyaslavKhmelnytsky State Pedagogical University named after Gregory Skovoroda, Oleksandr Dovzhenko Hlukhiv National Pedagogical University, Horlivka Institute for Foreign Languages (part of Donbas State Pedagogical University), Luhansk Taras Shevchenko National University, Dnipro State Technical University, Oles Honchar Dnipro National University, Donbas State Pedagogical University, Drohobych Ivan Franko State Pedagogical University, Zhytomyr Ivan Franko State University, Zaporizhzhia National University, Izmail State University of Humanities, KamianetsPodilskyi Ivan Ohiienko National University, Kyiv National Linguistic University, Taras Shevchenko National University of Kyiv, Kyiv Slavonic University, Borys Grinchenko Kyiv University, Classic Private University, Kramatorsk Institute of Economics and Humanities, Kryvyi Rih National University, Ivan Franko National University of Lviv, Mariupol State University, International Humanitarian University, Bogdan Khmelnitsky Melitopol State Pedagogical University, Mukachevo State University, National Metallurgical Academy of Ukraine, National Aviation University, National Pedagogical Dragomanov University, National University of Ostroh Academy, Vasyl Stefanyk Precarpathian National University, Sumy State University, V.I. Vernadsky Taurida National University, Ternopil Volodymyr Hnatiuk National Pedagogical University, Uzhhorod National University, Ukrainian Institute of Linguistics and Management, Pavlo Tychyna Uman State Pedagogical University, Alfred Nobel University, V. N. Karazin Kharkiv National University, Kherson State University, Khmelnytsky National University, Bohdan Khmelnytsky National University of Cherkasy and many others. 
According to the analysis of $\mathrm{M}$. Ikonnikova [14, p. 206-212], in 2016-2017, the most popular specializations were: 035.04 - Germanic languages and literature; 035.05 - Romanic languages and literature (including translation); 035.06 - Oriental languages and literature (including translation); 035.10-Applied Linguistics. In 2006, the total number of graduates in this field was 4,368 people, and in $2016-5,975$ people, which indicates a positive trend with the equivalent of $26.9 \%$ [5].

The last decade has seen an increase in the number of applicants for the faculties of foreign philology. Moreover, there is a clear trend towards a transition to a two-stage system of professional training, which is regulated by higher educational standards in Ukraine.

Also, the training of future teachers of foreign languages is carried out for the specialization area 014.02 "Secondary education (Language and literature (with the indication of a language))". The advantages of such training are the mastery of three foreign languages, the opportunity to participate in practical teaching activities, close cooperation with schools, etc. The courses of the educational programme can be obligatory and optional. The obligatory ones include:

1. The cycle of general training, which consists of humanitarian training (History and culture of Ukraine, Ukrainian language, Philosophy, Political and sociological sciences, Occupational safety and health, Physical education) and fundamental training (ICT, Developmental Physiology, Latin, History of Language, Lexicology);

2. The cycle of professional training, which includes psychological and pedagogical training (Pedagogy, History of pedagogy, Psychology) and scientific training (Practice of oral and written speech, Practical grammar, Practical phonetics, Methodology of teaching foreign languages, History of foreign literature, Theoretical phonetics, Country studies, Applied linguistics).

In the pedagogical and methodological literature, there are many positions expressed on the structure of professional competence [1, p. 8-14, 4, p. 76-77, 9, p. 92-95]. However, despite all the differences, almost all methodologists and teachers attach great importance to the formation and development of foreign language communicative competence of students of pedagogical universities, in particular, language students. Therefore, the communicative competence of future foreign language teachers is considered as an integral part of their professional competence [3, p. 53-55].

According to M.M. Cherniy, foreign language communicative competence elements are the following ones: ability to use foreign language adequately during live communication, selfcontrol and conscious responsibility for their own communicative behaviour, self-development and improvement, ideal orientation in the spheres and styles of communication, correct choice of verbal and nonverbal means and ways of expressing one's own opinions, successful establishment and maintenance of contact with a foreign interlocutor, ability to change the strategy and speech behaviour depending on the communicative situation [13].

In higher educational institutions of Ukraine, the methods of teaching foreign languages are mainly based on verbal, explanatory and illustrative, problembased and research issues. Moreover, the practical training of future language teachers involves writing tests, articles, essays, reviews, resumes, notes, crossword puzzles, participation in language games, preparation of speech tasks, creative work, situational modeling, independent work based on professional magazines, websites, participation in volunteer projects, etc. The use of interactive methods, which involve "student-student" relationships in order to master the practical principles of collective learning activities during seminars, are also considered to be rather effective. This provides an opportunity to develop and improve communicative skills by justifying their opinions, conducting discussions and dialogues.

In the context of European standards of higher education in Ukraine and modular education based on credits, theorists and practitioners focus on both independent work and practical sessions. According to O. Popova [8, p. 83-88], the traditional interactive forms, that have been actively used and associated with speech training, are round table discussions, an arena of negotiations (discussion and definition of effective approaches to solving problems), debates (learning to think logically and justify your own opinion, speak clearly if the interlocutor has a different view), practical seminars (development of practical oral skills). New active forms can include business games (a bank of ideas which teaches to deal with unusual situations), exhibitions and fairs of pedagogical ideas (demonstration of knowledge and skills in the field of language teaching).

Conclusion and propositions. As a result of our research, Ukraine does not stand aside the integration of the most modern methods and techniques of teaching into the process of training future foreign language teachers. The task of higher educational institutions of Ukraine is to modernize the teaching methods that would meet the needs of the modern society. It can be also concluded that the number of applicants for the faculties of foreign philology is increasing each year in Ukraine. Based on the analysis of educational programmes, which are implemented for the training of future foreign language teachers, it should be noted that Ukrainian higher educational institutions provide high quality training at the faculties of foreign philology. Development of foreign language communicative competence is also considered by 
Ukrainian universities as a very important issue while training future foreign language teachers. In view of this, interactive methods are being widely introduced. Among the most popular ones, we can note discussions, an arena of negotiations, debates, business games, etc.

Development of the conceptual model related to the formation of foreign language communicative competence of future teachers of foreign languages can be considered as the further area of our research.

\section{References:}

1. Болотов В.А. Компетентностная модель: от идеи к образовательной программе. Педагогика. 2003. № 10. С. 8-14.

2. Вовк О.І. Комунікативно-когнітивна компетентність майбутніх фрілологів: нова парадигма сучасної освіти. Черкаси: вид. Чабаненко Ю.А. 2013. $500 \mathrm{c}$.

3. Гизатулина Р.Ф. Развитие иноязычной коммуникативной компетенции студента-филолога. Филологические науки. Вопросы теории и практики. Тамбов: Грамота. 2013. № 2 (20). С. 53-55.

4. Горюнова Е.Р. Формирование профессиональной компетентности. Аккредитация в образовании. 2007. С. 76-77.

5. Інформаційна система «Конкурс». URL: http:// vstup.info (дата звернення: 10.03.2021).

6. Освіта.ua. URL: https://ru.osvita.ua/vnz/guide/ search-17-0-0-133-125.html (дата звернення: 10.03.2021).

7. Пентилюк М.І. Стратегічні орієнтири підготовки майбутнього вчителя-словесника. Дивослово. 2014. № 11. C. 2-6.
8. Попова, О. Педагогічні умови професійно-мовленнєвої підготовки майбутніх перекладачів китайської мови в умовах університетської освіти. Науковий вісник Південноукраїнського національного педагогічного університету імені К. Д. Ушинського. 2016. № 5 (112). C. 83-88.

9. Равен Дж. Компетентность в современном обществе: выявление, развитие и реализация. Москва : Когнито-Центр. 2002. 396 с.

10.Семеног О.М. Професійна підготовка майбутніх учителів української мови та літератури : монографія. Суми : ВВП Мрія-1 ТОВ, 2005. $404 \mathrm{c}$.

11. Семиченко В.А. Концепция целостности и ее реализация в профессиональной подготовке будущих учителей : автореф. дис. ... д-ра психол. наук : 19.00.0. Киев, 1992. 43с.

12.Царик О.М. Особливості профресійної підготовки учителів-фрілологів у Галичині на початку XX ст. Науковий вісник ужгородського університету. Серія: Педагогіка. Соціальна робота. 2016. № 1 (38). С. 312-315.

13.Черній М.М. Структура комунікативної культури вчителя іноземної мови. URL: http://www. irbis-nbuv.gov.ua/cgi-bin/irbis_nbuv/cgiirbis_64. exe?C21COM=2\&I21DBN=UJRN\&P21DBN=UJRN\&IMAGE_FILE_DOWNLOAD=1\&Image _ file_name=PDF/Sitimn_2013_36_99.pdf (дата звернення: 10.03.2021).

14.Ikonnikova M. Some general characteristics of future philologists' professional training at Ukrainian universities. Освітні обрії. 2020. № 1(50). C. 206-212.

\footnotetext{
Сердюченко Ю. О. Вітчизняний досвід підготовки майбутніх учителів іноземних мов із використанням інтерактивних технологій

Статтю присвячено окремим питанням підготовки майбутніх учителів іноземної мови та фоормування іншомовної комунікативної компетентності з використанням інтерактивних технологій у вищих навчальних закладах України. Зәадується, що комунікативна компетентність як запорука профресійного становлення майбутніх учителів іноземних мов історично посідає чільне місце, оскільки саме мовленню здавна приділялася основна увага. У статті виокремлюються компетентності та компетенції, яких має набути майбутній учитель іноземної мови. Визначено фракультети, на яких відбувається профресійна підготовка вчителів іноземної мови в українських закладах вищої освіти. Надано перелік провідних університетів України, де готують майбутніх учителів іноземної мови. У статті висвітлено спеціалізації на фракультетах іноземної мови, які набули найбільшої популярності серед українських студентів. З'ясовано, що за останнє десятиріччя спостерігається тенденція до збільшення претендентів на навчання на фракультетах іноземної філології. Особливу увагу приділено спеціальності 014.02 «Середня освіта (Мова та література (із зазначенням мови)» щодо переваг навчання на цій спеціальності з визначенням обов'язкових предметів освітньо-профресійної та наукової програми. У межах профресійної підготовки майбутніх учителів іноземної мови, які навчаються за спеціальністю 014.02, провідні українські вищі навчальні заклади пропонують цикл загальної підготовки, який складається з гуманітарної та фундаментальної підготовки, а також цикл профресійної підготовки, який вміщує психолого-педагогічну та науково-педагогічну підготовку. У статті зазначається, що іншомовна комунікативна компетентність майбутніх учителів іноземної мови $\epsilon$ невід'ємною частиною професійної компетентності, а також висвітлено елементи іншомовної комунікативної компетентності. Із метою формування іншомовної комунікативної компетентності майбутніх учителів іноземної мови українські заклади вищої освіти запроваджують низку методів, зокрема інтерактивних технологій, під час навчання іноземній мові, які перелічено у статті.
}

Ключові слова: вітчизняний досвід, інтерактивні технології, профресійна компетентність, іншомовна комунікативна компетентність, профресійна підготовка. 